\title{
ANALISIS HARGA WAJAR SAHAM DENGAN METODE DISCOUNTED CASH FLOW PT BANK TABUNGAN NEGARA TBK PERIODE 2013-2017
}

\author{
Redi Nurhadiman ${ }^{1}$, Desy Septariani, \\ ${ }^{1,2}$ Program Studi Pendidikan Ekonomi, \\ Fakultas Ilmu Pengetahuan dan Pendidikan Sosial, \\ Universitas Indraprasta PGRI \\ E-mail:desy_septa@yahoo.com \\ E-mail: redinurhadiman46@gmail.com
}

Diterima: 07 Oktober 2019; Direvisi: 11 November 2019; dipublikasikan: 21 Desember 2019

\begin{abstract}
The purpose of the research is to analyze and find out the fair price of the shares of PT Bank Tabungan Negara, Tbk for the period 2013-2017. The research method use quantitative descriptive methods with analyze discounted cash flow methods with proxy earning per share, dividen pay out ratio, price earning ratio dan required rate of return. The result research in 2013, 2014 and 2016 stock prices were undervalued while in 2015 and 2017 the stock prices were overvalued. Then based on the analysis using the graph of stock price movements of PT Bank Tabungan Negara, Tbk for the period 2013-2017, the results show that in 2013 and 2014 the share price of PT Bank Tabungan Negara, Tbk was almost close to its fair price, while in 2015, 2016 and 2017 the stock price PT Bank Tabungan Negara, Tbk has reached and exceeded its fair price.
\end{abstract}

Keywords : Fair Price of Stock, Discounted Cash Flow

\begin{abstract}
ABSTRAK
Tujuan dari penelitian adalah untuk menganalisis dan mengetahui harga wajar saham PT Bank Tabungan Negara, Tbk periode 2013-2017. Metode penelitian yang digunakan adalah metode deskriptif kuantitatif dengan menganalisis metode discounted cash flow dengan proksi earning per share, dividen pay out ratio, price earning ratio dan required rate of return. Hasil penelitian adalah pada tahun 2013, 2014 dan 2016 harga saham bersifat undervalued sedangkan pada tahun 2015 dan 2017 harga saham bersifat overvalued. Kemudian berdasarkan analisa menggunakan grafik pergerakan harga saham PT Bank Tabungan Negara, Tbk periode 20132017, diperoleh hasil bahwa pada tahun 2013 dan 2014 harga saham PT Bank Tabungan Negara, Tbk hampir mendekati harga wajarnya, sedangkan pada tahun 2015, 2016 dan 2017 harga saham PT Bank Tabungan Negara, Tbk telah mencapai dan melampaui harga wajarnya.
\end{abstract}

Kata kunci : Harga Wajar Saham, Discounted Cash Flow 


\section{PENDAHULUAN}

Pasar modal merupakan instrumen jangka panjang (jangka waktu lebih dari 1 tahun) seperti saham, obligasi, waran, right, reksa dana, dan berbagai instrumen derivatif seperti option, futures, dan lain-lain (www.idx.co.id). Pada dasarnya, pasar modal (capital market) sama dengan pasar lain, yakni tempat penjual dan pembeli bertemu dan melakukan transaksi. Sesuai namanya, perdagangan yang di transaksikan di pasar modal adalah modal dan aktiva yang mewakili modal seperti saham, surat utang dan turunannya (derivatif) baik saham maupun surat utang (Moechdie, 2012: 26).

Investasi di pasar modal, nilai harga saham merupakan faktor penting. Oleh karena itu, para investor harus memperhatikan pergerakan harga saham yang dipengaruhi oleh faktor fundamental, yang terdiri dari intern meliputi keadaan para emiten seperti laporan kinerja keuangan, laporan dan kebijakan manajemen, aksi korporasi, public expose, pembagian deviden, serta perubahan strategi dalam rapat umum pemegang saham, akan menjadi informasi penting bagi para investor di pasar modal. Sedangkan fakor ekstern meliputi kebijakan pemerintah, perubahan nilai tukar rupiah terhadap dollar (kurs), keadaan inflasi dan penetapan suku bunga oleh Bank Indonesia.

Sebagian besar investor, merasa kebingungan ketika mereka untuk pertama kalinya terjun ke dunia pasar modal. Mereka bingung harus memulai dari mana dan apa yang harus di pelajari, karena saham memang terkesan sebagai sesuatu yang canggih dan hanya bisa dimengerti oleh orang-orang tertentu (Hidayat, 2017: 1). Sebelum melakukan investasi atau transaksi saham, tentunya investor perlu membekali dirinya dengan memahami beberapa metode analisis yang mudah diaplikasikan sesuai dengan pribadi dan kenyamanan investor, maka resiko tersebut dapat dicegah. Bahkan bukan tidak mungkin aset atau dana yang dimiliki berpotensi untuk berkembang pesat. Metode analisis yang digunakan untuk menganalisis atau memprediksi pergerakan terhadap suatu harga saham jumlahnya sangat banyak. Oleh karena itu, investor cukup memilih metode yang mampu dipahami dan diterapkan dalam memprediksi nilai yang terkandung dalam saham yang akan dibelinya.

Saham adalah tanda penyertaan kepemilikan seseorang atau badan dalam suatu perusahaan. Selembar saham adalah selembar kertas yang menerangkan bahwa pemilik kertas tersebut adalah pemilik (berapapun porsinya) dari suatu perusahaan yang menerbitkan saham tersebut, sesuai porsi kepemilikannya yang tertera pada saham (Masri dan Wahbi, 2017: 73). Saham adalah suatu bukti kepemilikan suatu perusahaan riil, dimana jika seseorang membeli saham maka sama dengan ia membeli bisnis dari perusahaan yang menerbitkan saham tersebut (Wira, 2014: 5)..

Analisis fundamental juga dipakai untuk menganalisis tingkat kewajaran harga suatu saham. Mengukur tingkat kewajaran suatu saham biasanya adalah dengan membandingkan rasio-rasio keuangan tertentu dengan saham lainnya yang bergerak dalam bisnis yang sama. Pada dasarnya, analisis fundamental digunakan untuk mengetahui apakah suatu saham termasuk kategori mahal (overvalued), wajar (fair) atau murah (undervalued) untuk dibeli (Wira, 2014: 3). Mengetahui fundamental suatu saham akan sangat membantu investor untuk menghindari membeli saham yang berkinerja buruk. Analisis fundamental adalah suatu pendekatan yang mempelajari kinerja suatu perusahaan atau emiten secara menyeluruh yang memperhitungkan berbagai faktor, seperti kinerja perusahaan, analisis persaingan usaha, analisis industri, analisis makro dan mikro (Wira, 2014: 3). Pendapat lain mengatakan, analisis fundamental adalah suatu kegiatan membaca laporan keuangan dan dokumen-dokumen lainnya terkait suatu perusahaan, sehingga akhirnya diperoleh kesimpulan apakah sahamnya tersebut layak untuk diinvestasikan atau tidak (Hidayat, 2017: 121).

Untuk mengetahui harga wajar atau nilai intrinsik suatu saham, metode analisis fundamental yang sering digunakan oleh para investor profesional salah satunya adalah dengan 
menerapkan metode discounted cash flow (arus kas terdiskon). Metode ini menganut konsep time value of money yang memproyeksikan arus kas yang akan diterima di masa yang akan datang (future value) untuk selanjutnya di nilai sekarangkan (present value) dengan faktor diskonto (Wira, 2014: 132). Discounted cash flow di pilih karena merupakan metode investasi yang cukup efektif dalam analisis fundamental dan sering digunakan para investor professional untuk mengetahui nilai intrinsik atau harga wajar serta mahal atau murahnya suatu saham.

Salah satu saham yang menarik untuk dianalisis menggunakan metode discounted cash flow adalah saham PT. Bank Tabungan Negara, Tbk (Kode saham : BBTN), karena saham ini memiliki laporan kinerja keuangan yang cukup bagus dimana selalu menghasilkan laba setiap tahunnya, dimana itu memenuhi kriteria dari metode discounted cash flow.

Harga wajar saham sering juga disebut sebagai nilai intrinsik suatu saham (intrinsic value) yaitu suatu nilai saham yang dianggap benar-benar mewakili performa atau kinerja suatu perusahaan (Wira, 2014: 126). Dengan mengetahui nilai intrinsik suatu saham, investor dapat mengatur strategi yang tepat pada saham-saham bagus pada saat harga saham tersebut menurun dengan tajam (Siregar, 2018: 100).

Discounted Cash Flow (DCF) adalah metode valuasi saham yang menggunakan konsep time value of money. Teori yang mendasari metode ini adalah seluruh uang yang mengalir di perusahaan di masa depan (future value), bila didiskontokan merupakan nilai wajar saham tersebut (present value), atau biasa disebut dengan arus kas terdiskon (Wira, 2014: 142). Discounted cash flow juga merupakan metode dengan perhitungan menggunakan arus kas seperti net income, free cash flow, dan operating cash flow yang di hitung future value nya lalu didiskontokan untuk mendapatkan nilai harga wajar saham (Filbert, 2017: 175). Discounted cash flow adalah suatu metode investasi dengan menggunakan analisis fundamental, untuk membeli saham-saham yang di perdagangkan di bawah harga wajarnya, serta memiliki fundamental yang baik dan menjual kembali saham tersebut ketika harganya sudah mencapai atau melebihi harga wajar (nilai intrinsik) nya. Penelitian ini memfokuskan pada harga wajar saham dengan metode discounted cash flow menggunakan indikator rasio earning per share, dividen pay out ratio, price earning ratio dan required rate of return pada PT. Bank Tabungan Negara, Tbk periode 2013-2017.

Earning Per Share atau laba per saham, adalah rasio yang digunakan untuk untuk mengukur tingkat profitabilitas suatu perusahaan. Semakin besar rasio ini, akan semakin baik (Wira, 2014: 94).

Dividen payout ratio adalah rasio yang menghitung nilai dividen yang dibagikan kepada pemegang saham dari laba bersih yang dihasilkan perusahaan (Moechdie, 2012: 284).

Price Earning Ratio, adalah rasio yang dihitung dengan membagi harga saham saat ini dengan earning per share. PER menggambarkan seberapa banyak investor menghargai saham tersebut. Asumsinya, semakin kecil nilai PER suatu emiten itu semakin bagus dan murah (Wira, 2014: 94)

Required Rate of Return, merupakan tingkat pengembalian yang diharapkan oleh investor untuk mendapatkan keuntungan yang layak dalam berinvestasi saham (Wira, 2014: 148).

\section{METODE}

Penelitian berada di Bursa Efek Indonesia (BEI) dengan mengunjungi website http://www.idx.co.id yang telah mempublikasikan laporan keuangan tahunannya. Pengambilan data dilakukan dari tahun 2013 sampai 2017.

Populasi dalam penelitian ini adalah semua perusahaan yang terdaftar di BEI periode 2013 sampai 2017, sedangkan sampel penelitian adalah PT.Bank Tabungan Negara, Tbk. Metode pengambilan sampelnya adalah purposive sampling. Data yang digunakan dalam 
Volume 11, No. 3, Desember 2019, pp.217-224

e-ISSN: 2502-5449

p-ISSN: 2085-2266

DOI : 10.30998/sosioekons.v11i3.

penelitian ini adalah data sekunder yang berupa laporan keuangan dan annual report. metode pengumpulan data dalam penelitian ini menggunakan metode dokumentasi. Metode analisis data dengan deskriptif kuantitatif

\section{HASIL DAN PEMBAHASAN}

Tabel 1

Hasil Perhitungan Harga Wajar Saham BBTN Periode 2013-2017

\begin{tabular}{cccccccccc}
\hline No & Tahun & $\begin{array}{c}\text { Rata- } \\
\text { rata } \\
\text { EPS } \\
\text { Growt } \\
\boldsymbol{h} \\
(\boldsymbol{\%})\end{array}$ & $\begin{array}{c}\text { Future } \\
\text { Value } \\
\text { Harga } \\
\text { Saham }\end{array}$ & $\begin{array}{c}\text { Rata- } \\
\text { rata } \\
\text { DPR } \\
(\boldsymbol{\%})\end{array}$ & $\begin{array}{c}\text { Future } \\
\text { Dividen }\end{array}$ & $\begin{array}{c}\text { Rata- } \\
\text { rata } \\
\text { PER } \\
(\mathbf{x})\end{array}$ & $\begin{array}{c}\text { Future } \\
\text { Value }\end{array}$ & $\begin{array}{c}\text { Required } \\
\text { Rate of } \\
\text { Return } \\
(\boldsymbol{\%})\end{array}$ & $\begin{array}{c}\text { Harga } \\
\text { Wajar }\end{array}$ \\
\hline 1. & 2013 & 20,67 & $3.161,9$ & 25 & 253,94 & 9,46 & $3.415,84$ & 14,17 & $1.760,91$ \\
\hline 2. & 2014 & 18,75 & $3.572,2$ & 26 & 298,36 & 10,62 & $3.870,56$ & 17,59 & $1.721,56$ \\
\hline 3. & 2015 & 9,32 & $2.048,5$ & 26 & 185,08 & 10,69 & $2.233,58$ & 15,38 & $1.092,32$ \\
\hline 4. & 2016 & 14,71 & $4.223,9$ & 24 & 325,66 & 9 & $4.549,56$ & 17,98 & $1.990,34$ \\
\hline 5. & 2017 & 19,13 & $5.961,7$ & 24 & 459,64 & 8,53 & $6.421,36$ & 17,65 & $2.848,78$ \\
\hline
\end{tabular}

Sumber : Hasil perhitungan peneliti

Setelah dilakukan perhitungan harga wajar saham dengan metode discounted cash flow, maka akan diketahui bagaimana kondisi harga saham perusahaan yang telah ditawarkan di Bursa Efek. Untuk mengetahui kondisi harga saham, diperlukan perbandingan antara harga wajar dari perhitungan metode discounter cash flow dengan harga pasar.

Adapun perbandingan antara perhitungan harga wajar dengan metode discounted cash flow dengan harga pasar saham PT Bank Tabungan Negara, Tbk periode 2013-2017 adalah sebagai berikut.

Tabel 2

Perbandingan Harga Pasar Dengan Harga Wajar Saham BBTN

Periode 2013-2017

\begin{tabular}{cllll}
\hline TAHUN & HARGA PENUTUPAN & $\begin{array}{l}\text { HARGA } \\
\text { WAJAR }\end{array}$ & $\begin{array}{l}\text { MARGIN OF } \\
\text { SAFETY }\end{array}$ & KONDISI \\
\hline 2013 & 870 & $1.760,91$ & $102,40 \%$ & Undervalued \\
\hline 2014 & 1.205 & $1.721,56$ & $42,87 \%$ & Undervalued \\
\hline 2015 & 1.295 & $1.092,32$ & $-15,65 \%$ & Overvalued \\
\hline 2016 & 1.740 & $1.990,34$ & $14,39 \%$ & Undervalued \\
\hline 2017 & 3.570 & $2.848,78$ & $-20,20 \%$ & Overvalued \\
\hline
\end{tabular}

Sumber : Hasil perhitungan peneliti

Berdasarkan tabel 2 perbandingan harga pasar dengan menggunakan harga penutupan per akhir Desember terhadap harga wajar saham pada PT. Bank Tabungan Negara, Tbk. Menurut hasil perhitungan discounted cash flow pada tahun 2013-2014 bersifat undervalued atau harga 
saham lebih rendah dari harga wajarnya, sedangkan pada tahun 2015 bersifat overvalued atau lebih tinggi dibandingkan harga wajarnya. Tahun 2016 harga saham bersifat undervalued namun pada tahun 2017 kembali bersifat overvalued.

Dari pendekatan metode discounted cash flow, bisa dilihat bahwa harga wajar saham PT. Bank Tabungan Negara, Tbk selama periode 2013-2017 cenderung meningkat setiap tahunnya, kecuali terjadi penurunan harga wajar pada tahun 2015 yang disebabkan oleh turunnya earning per share (EPS) pada tahun 2014, dimana laba bersih perusahaan turun sebesar $-28,58 \%$ dari Rp. 1.562.161.000.000 pada tahun 2013 menjadi Rp. 1.115.592.000.000 pada tahun 2014.

Secara teori jika laba bersih suatu perusahaan menurun sedangkan jumlah saham beredar tetap atau bertambah, maka laba bersih per saham (earning per share) pun akan ikut turun. Jadi dalam hal ini, kenaikan dan penurunan laba bersih perusahaan akan sangat berkaitan dengan kenaikan dan penurunan EPS dan dalam metode discounted cash flow, pertumbuhan EPS menjadi salah satu faktor yang sangat penting sebagai indikator untuk memproyeksikan pertumbuhan EPS dimasa yang akan datang.

Dengan mengetahui harga wajar saham pada tahun suatu periode, investor bisa membuat keputusan untuk membeli atau menjual saham tersebut sekaligus memaksimalkan potensi keuntungan yang bisa diperoleh. Sederhananya, ketika investor sudah mengetahui harga wajar suatu saham, selanjutnya adalah berusaha membeli saham tersebut dibawah nilai wajarnya dan menjual ketika mendekati atau melampaui harga wajarnya.

Analisis grafik harga saham PT. Bank Tabungan Negara, Tbk dibandingkan dengan harga wajarnya pada periode 2013-2017. Data yang disajikan adalah pergerakan harga saham secara bulanan dalam suatu periode.

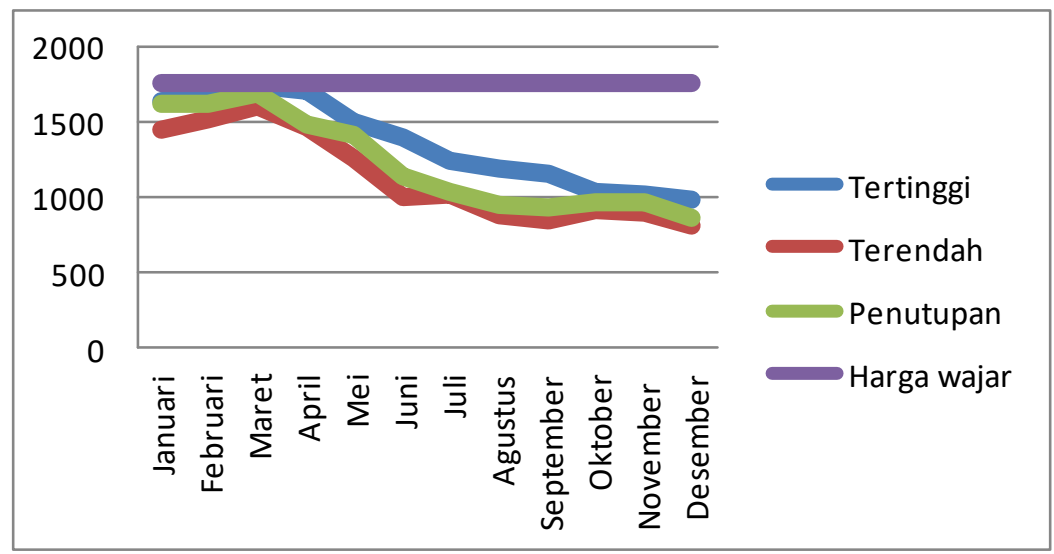

Sumber : www.investing.com dan hasil perhitungan peneliti

Gambar 1. Pergerakan harga saham dan harga wajar BBTN 2013

Berdasarkan grafik tersebut diketahui bahwa harga wajar saham PT. Bank Tabungan Negara, Tbk pada tahun 2013 adalah 1.760,91 dan pada bulan Maret sempat mencapai harga tertinggi di level 1.740 atau hampir mendekati harga wajarnya. 
Volume 11, No. 3, Desember 2019, pp.217-224

e-ISSN: 2502-5449

p-ISSN: 2085-2266

DOI : 10.30998/sosioekons.v11i3.

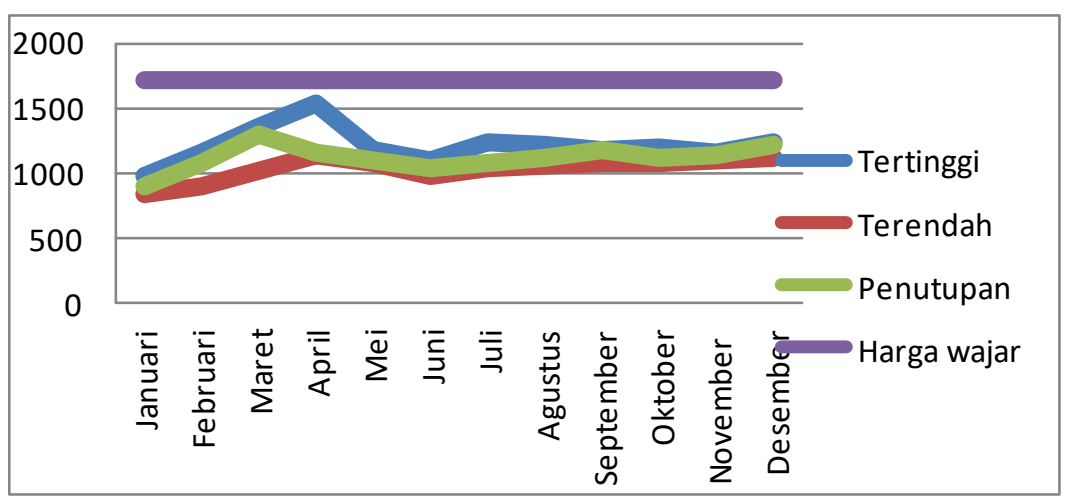

Sumber : www.investing.com dan hasil perhitungan peneliti

Gambar 2. Pergerakan harga saham dan harga wajar BBTN 2014

Berdasarkan grafik tersebut diketahui bahwa harga wajar saham PT. Bank Tabungan Negara, Tbk pada tahun 2014 adalah 1.760,91 dan pada bulan Maret sempat mencapai harga tertinggi di level 1.525 atau hampir mendekati harga wajarnya.

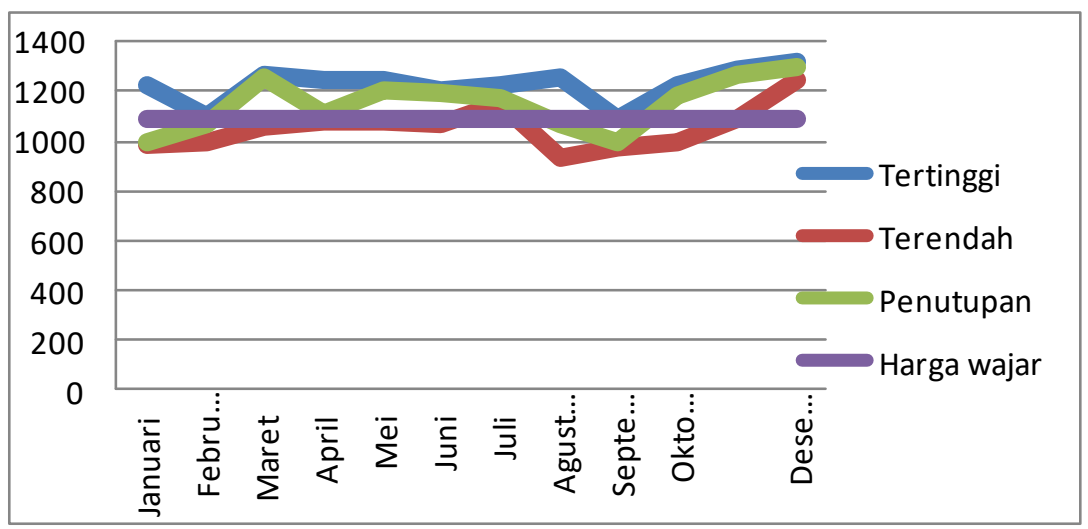

Sumber : www.investing.com dan hasil perhitungan peneliti

Gambar 3. Pergerakan harga saham dan harga wajar BBTN 2015

Berdasarkan grafik tersebut diketahui bahwa harga wajar saham PT. Bank Tabungan Negara, Tbk pada tahun 2015 adalah 1.092,34 dan pada bulan Desember sempat mencapai harga tertinggi di level 1.315 atau telah mencapai dan melampaui harga wajarnya.

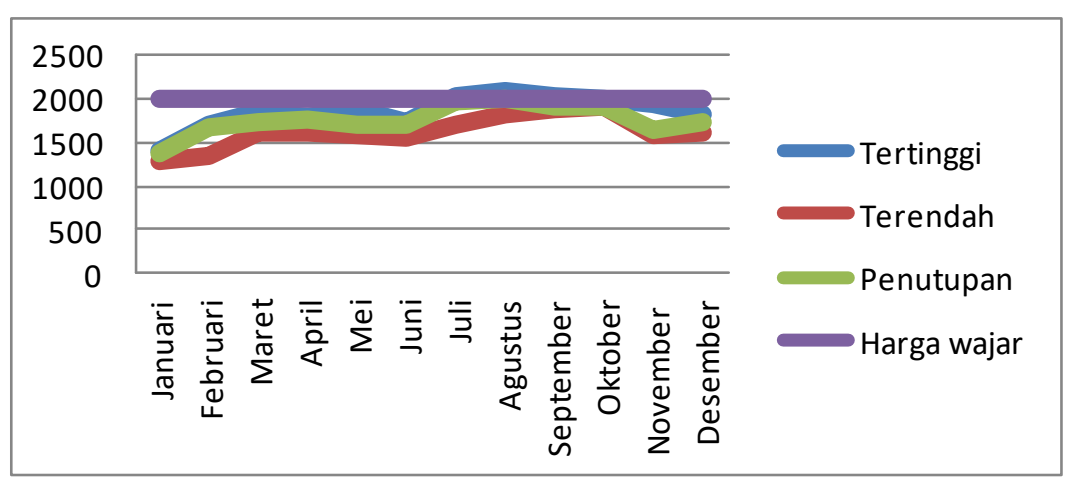

Sumber : www.investing.com dan hasil perhitungan peneliti

Gambar 4. Pergerakan harga saham dan harga wajar BBTN 2016 
Berdasarkan grafik tersebut diketahui bahwa harga wajar saham PT. Bank Tabungan Negara, Tbk pada tahun 2016 adalah 1.990,34 dan pada bulan Agustus sempat mencapai harga tertinggi di level 2.100 atau telah mencapai dan melampaui harga wajarnya.

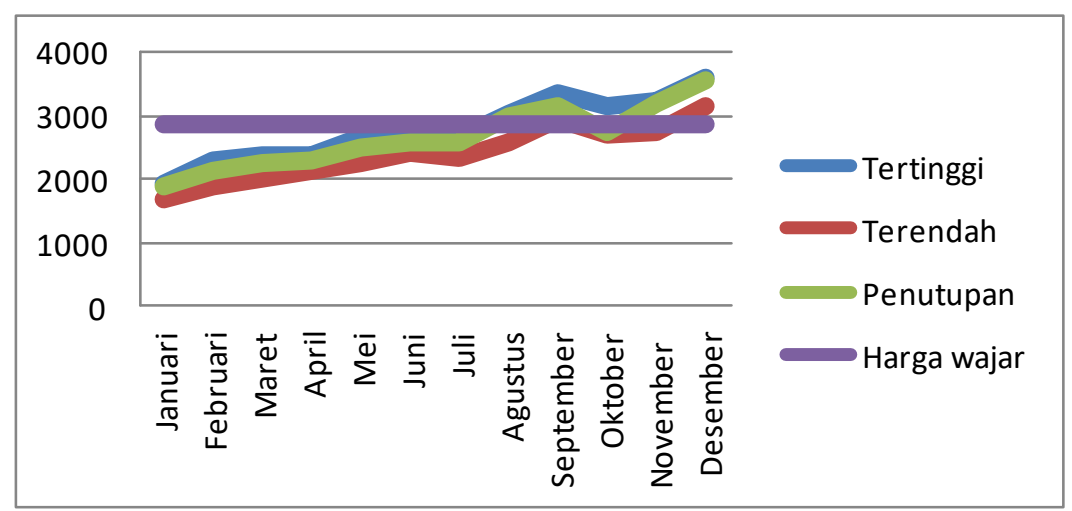

Sumber : www.investing.com dan hasil perhitungan peneliti

Gambar 5. Pergerakan harga saham dan harga wajar BBTN 2017

Berdasarkan grafik tersebut diketahui bahwa harga wajar saham PT. Bank Tabungan Negara, Tbk pada tahun 2017 adalah 2.848,78 dan pada bulan Desember sempat mencapai harga tertinggi di level 3.610 atau telah mencapai dan melampaui harga wajarnya.

\section{SIMPULAN}

Berdasarkan dari hasil penelitian, maka simpulannya adalah sebagai berikut: 1). Hasil perhitungan discounted cash flow, diperoleh harga wajar saham PT Bank Tabungan Negara, Tbk pada tahun 2013 yaitu Rp. 1.760,91, tahun 2014 Rp. 1.721,56, tahun 2015 Rp. 1.092,32, tahun 2016 Rp. 1.990,34 dan tahun 2017 Rp. 2.848,78. Sedangkan harga pasar berdasarkan harga penutupan pada tahun 2013 yaitu Rp. 870, tahun 2014 Rp. 1.205, tahun 2015 Rp.1.295, tahun 2016 Rp.1.740 dan tahun 2017 Rp. 3.570, sehingga pada tahun 2013, 2014 dan 2016 harga saham bersifat undervalued sedangkan pada tahun 2015 dan 2017 harga saham bersifat overvalued. 2). Hasil analisa menggunakan grafik pergerakan harga saham PT Bank Tabungan Negara, Tbk periode 2013-2017, diperoleh hasil bahwa pada tahun 2013 dan 2014 harga saham PT Bank Tabungan Negara, Tbk hampir mendekati harga wajarnya, sedangkan pada tahun 2015, 2016 dan 2017 harga saham PT Bank Tabungan Negara, Tbk telah mencapai dan melampaui harga wajarnya.

\section{DAFTAR RUJUKAN}

Filbert, Ryan dan William Prasetya. 2017. Investasi Saham ala Fundamentalis Dunia. Jakarta: Elex Media Komputindo

Hidayat, Teguh. 2017. Value Investing : Beat the Market in Five Minutes!. Jakarta: Elex Media Komputindo.

Masri, Zainal Arifin H. dan Abdul Azim Wahbi. 2017. Pasar Uang dan Pasar Modal. Jakarta : Unindra Press.

Moechdie, Abi Hurairah. 2012. Gerbang Pintar Pasar Modal. Jakarta: Capital Bridge Advisory. 


\section{sosio e-kons}

Volume 11, No. 3, Desember 2019, pp.217-224

e-ISSN: 2502-5449

p-ISSN: 2085-2266

DOI : 10.30998/sosioekons.v11i3.

Siregar, William Ardian. 2018. The Kingvestor : Bagaimana Memperoleh

Keuntungan Lebih dari 100\% Dalam Berinvestasi Saham. Yogyakarta: Media Pressindo.

Sugiyono. 2017. Metode Penelitian Kuantitatif, Kualitatif dan R\&D. Bandung: Alfabeta.

Wira, Desmond. 2014. Buku Wajib Investor Saham : Analisis Fundamental

Saham.

Jakarta : Exceed. 